\section{Effect of Early Bilateral Decompressive Craniectomy on Outcome for Severe Traumatic Brain Injury}

\section{Ağır Kafa Travmasında Erken Bilateral Dekompresif Kraniektominin Sonuca Etkisi}

\begin{abstract}
AIM: Debate continues as to whether decompressive craniectomy (DC) is an effective treatment for severe traumatic brain injury (STBI). DC is mostly used as a second tier treatment option. The aim of this study was determined whether early bilateral DC is effective as a first tier treatment option in patients with STBI.

MATERIAL and METHODS: The study compared two groups. Group 1 comprised 36 STBI patients for whom control of intracranial pressure (ICP) was not achieved with conservative treatment methods according to radiological and neurological findings. These patients underwent bilateral or unilateral DC as a second tier treatment. Group 2 comprised 40 STBI patients who underwent early bilateral DC as a first tier treatment.

RESULTS: Group 2 patients had a mean better outcome than Group 1patients, especially for patients with a GCS 6-8. Postoperative ICP was lower in Group 2 patients than Group 1 patients.

CONCLUSION: This study indicates that early bilateral DC can be effective for controlling ICP in STBI patients. It is likely the favorable outcome results for Group 2 patients reflects the relatively short time between trauma and surgery. Therefore, these data indicate early bilateral DC can be considered as a first tier treatment in STBI patients.
\end{abstract}

KEYWORDS: Severe traumatic brain injury, Decompressive craniectomy, Intracranial pressure

\section{ÖZ}

AMAÇ: Dekompresif kraniektominin (DK) ağır kafa travmasında (AKT) etkin bir tedavi yöntemi olup, olmadığ1 tartışması devam etmektedir. DK genelde ikinci basamak tedavi seçeneği olarak kullanılmaktadır.Bu çalışmanın amacı, AKT hastalarda erken bilateral DK birinci basamak tedavi seçeneği olarak etkinliğini belirlemektir.

YÖNTEM ve GEREÇ: Bu çalışmada iki grup karşılaştırıldı. Grup 1, radyolojik ve nörolojik bulgulara gore konservatif tedavi metodları ile kafa içi basınç (KIB) kontrolu sağlanamamış 36 AKT hasta içermekteydi. Bu hastalara ikinci basamak tedavi seçeneği olarak bilateral veya unilateral DK yapıldı. Grup 2'de, 40 AKT hastaya birinci basamak tedavi seçeneği olarak erken bilateral DK yapıldı.

BULGULAR: Grup 2'deki hastaların iyileşme sonuçları, özellikle Glasgow koma skalası 6-8 olan hastalar belirgin olmak üzere grup 1den daha iyi olarak tespit edildi. Postoperatif KIB grup 2 deki hastalarda grup 1 den daha düşüktü.

SONUÇ: Bu çalışma, AKT hastalarda erken bilateral DK nin KIB kontrolü için etkin olabileceğini göstermektedir. Grup 2'deki hastaların sonuçlarının istenilen düzeylerde olması cerrahi ile travma arasındaki kısa intervalin ilişkisini yansitmaktadır. Bu veriler erken bilateral DC AKT olgularda birinci basamak tedavi seçeneği olarak düşünülmelidir

ANAHTAR SÖZCÜKLER: Ağır kafa travması, Dekompresif kraniektomi, Kafa içi basınç

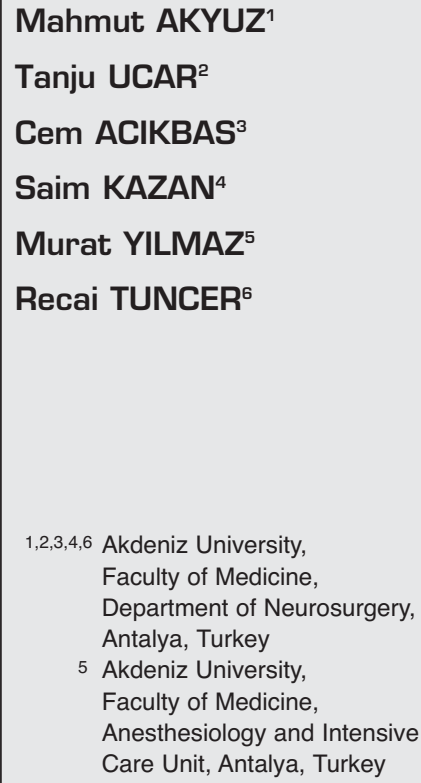

Received : 17.11.2009

Accepted : 03.12.2009

Correspondence address:

Mahmut AKYUZ

Akdeniz University, Faculty of Medicine,

Department of Neurosurgery,

Antalya, TURKEY

Phone: +90 2422496207

E-mail: mahmutakyuz@akdeniz.edu.tr 


\section{INTRODUCTION}

Treatments for STBI patients are largely inadequate. Mortality and morbidity rates for STBI patients remain high despite improvements in emergency care, imaging, critical care, medical and surgical treatment options, and rehabilitation It may be possible to achieve better outcomes with modulations and developments in treatment principles. In general, STBI patients are initially treated with first tier standard medical treatment, and second tier options such as high dose barbiturate therapy, mild hypothermia, mild hyperventilation and DC are used if this proves ineffective in reducing intracranial pressure (ICP) $(10,18,20,21,25,26)$.

In the present study, we evaluated the effect of early bilateral DC as a first tier treatment in STBI patients.

\section{MATERIAL and METHODS}

\section{Patients}

The study involved 252 STBI patients (104 female and 148 male) who were admitted to the Akdeniz University School of Medicine between January 2003 and November 2008. All patients were assessed according to age, gender, Glasgow Coma Score (GCS), presence of systemic injury as Injury Severity Score (ISS), timing for DC and Glasgow Outcome Score (GOS).

\section{Patient Selection}

Patients were arranged into two groups. Group 1 contained 36 STBI patients treated between January 2003 and February 2006. Group 2 contained 40 STBI patients treated between March 2006 and November 2008. The patient selection criterion for the study was the initial GCS; GCS of 8 or below was regarded as "severe head injury" as evaluated after the primary resuscitation in the emergency service.

The patients underwent unilateral or bilateral DC (as a second tier treatment option) and included those undergoing surgical decompression after trauma due to intracranial hypertension with clinical deterioration that had been resistant to aforementioned medical therapies in group 1. Early bilateral DC (as a first tier treatment option) was performed on patients with opening ICP above 25 $\mathrm{mm} \mathrm{Hg}$ in group 2.Both of groups were monitored intraventricularly.

\section{Patient Management}

After hospital admission, all patients underwent primary resuscitation and stabilization as well as surgical therapy according to the European Brain Injury Consortium (EBIC)-Guidelines for management of STBI (19).

All patients underwent axial cranial computerized tomography (CCT). CCT scans were obtained at admission, before surgical decompression, 24 hours after admission, after each surgical intervention and before discharge. Additional scans were obtained if necessary (e.g., due to increased ICP or neurological deterioration).

A ventricular catheter was inserted in all patients. ICP values were monitored continuously and were recorded before and after DC treatment. All patients were positioned in a $30^{\circ}$ head up position, sedated initially with benzodiazepine and an opioid. All patients were normovolemic with normal electrolyte balance. Mannitol was administered as repeated boluses $(0.25-1 \mathrm{~g} / \mathrm{kg}$ of body weight) according to serum osmolarity. Cerebrospinal fluid (CSF) was drained via intraventricular catheter if the ventricular pressure exceeded $20 \mathrm{mmHg}$. Barbiturate therapy and hypothermia were not used. Same medical therapy was performed for both groups.

For Group 1 patients, surgical treatment was considered in cases of a large volume hyperdense lesion as determined by CCT scan. The indications were as follows: a) a thickness superior to $1 \mathrm{~cm}$ in cases of acute subdural hematoma and a volume superior to $30 \mathrm{ml}$ in cases of intracerebral hematoma; b) a deviation from the supratentorial midline $>5$ $\mathrm{mm}$ with lateral ventricle compression; and c) obliteration of mesencephalic cisterns. The indication for DC also included appearance or deterioration of diffuse unilateral or bilateral brain swelling (according to CT scan) in correlation with neurological deterioration; dilatation of pupil, unresponsiveness to light, ICP increase to more than $30 \mathrm{~mm} \mathrm{Hg}$, and/or reduction in cerebral perfusion pressure to less than $60 \mathrm{~mm} \mathrm{Hg}$ for a period longer than 15 minutes, and failure to respond to the maximum medical treatment mentioned above.

For Group 2 patients, after primary resuscitation and stabilization, early bilateral DC was performed on patients with opening ICP above $25 \mathrm{~mm} \mathrm{Hg}$. Extracerebral clots were also evacuated. 


\section{Exclusion Criteria}

DC was not performed on patients with bilateral dilated and fixed pupils, a GCS of 3, over 70 years old, or with life-threatening medical conditions.

\section{Decompressive Surgical Procedures}

Patients were placed in a supine position and ventricular punctures were performed at Kocher's point on the side opposite to the lesion. An external ventricular drainage catheter $(E V D)$ was connected to the continuous cerebral perfusion pressure monitor via a transducer device. This monitoring system continuously measured mean ventricular pressure.

The unilateral/bilateral decompression procedure involved making a large unilateral/bilateral curvilinear incision in the fronto-temporo-parietal region, followed by the creation of a myocutaneous flap and then a craniectomy with elevation of a free fronto-temporo-parietal bone flap (Figure 1A,B,C,D). A bone rim was left over the superior sagittal sinus to prevent complications related to the sinus. Special care was taken to remove the temporal bone down to the base of the cranium. The dura was then opened and accumulated extra-axial fluid was drained. The dura was then enlarged with the temporal fascia in a " star " manner. The bone flaps were inserted under abdominal fat tissues and were replaced 3-6 months after surgery in surviving patients.

\section{Data Collection}

The initial GCS score, intracranial pathological findings and the time interval between injury and craniectomy were documented, as were the initial ICP readings, which were measured after ventricular tapping. The ventricular pressures obtained after craniectomy and opening of the dura were considered to be DC-state ICP. Ventricular pressure values were collected using the continuous monitor during surgery and the postoperative period (range 7-15 days). ICP mean values were recorded each hour. In addition, any instances of hypotension (systolic arterial pressure $<90 \mathrm{~mm} \mathrm{Hg}$ for $>10 \mathrm{~min}$ ), subdural hygroma, hydrocephalus, septic shock, and meningitis were documented.

\section{Outcome}

Patients were evaluated by neurosurgical faculty staff, house staff, and rehabilitation medicine physicians at both discharge from the hospital and follow-up appointments. The neurological outcome was determined according to the Glasgow Outcome Score $(\mathrm{GOS})^{8}$. Under this rating system, a GOS of 1 describes death; a score of 2 , a persistent vegetative state; a score of 3 , a severe disability (conscious but disabled); a score of 4 , a moderate disability (disabled but independent); and a score of 5, an excellent recovery with return to baseline functional status. Prognostic evaluations in survivors were determined using the GOS assessment at 12 months after the trauma. GOS evaluations were made by the physician either in person or via the telephone. A GOS between 1-3 was categorized as an "unfavorable" outcome, while a score of 4-5 was deemed a "favorable" outcome.

\section{Statistical Analysis}

Descriptive statistics including mean, standard deviation and range were calculated for continuous parameters. Comparisons between groups were analyzed using Chi square test, Fisher's exact test and Paired-Samples t-test. Differences were considered significant when $p<0.05$. Data analysis
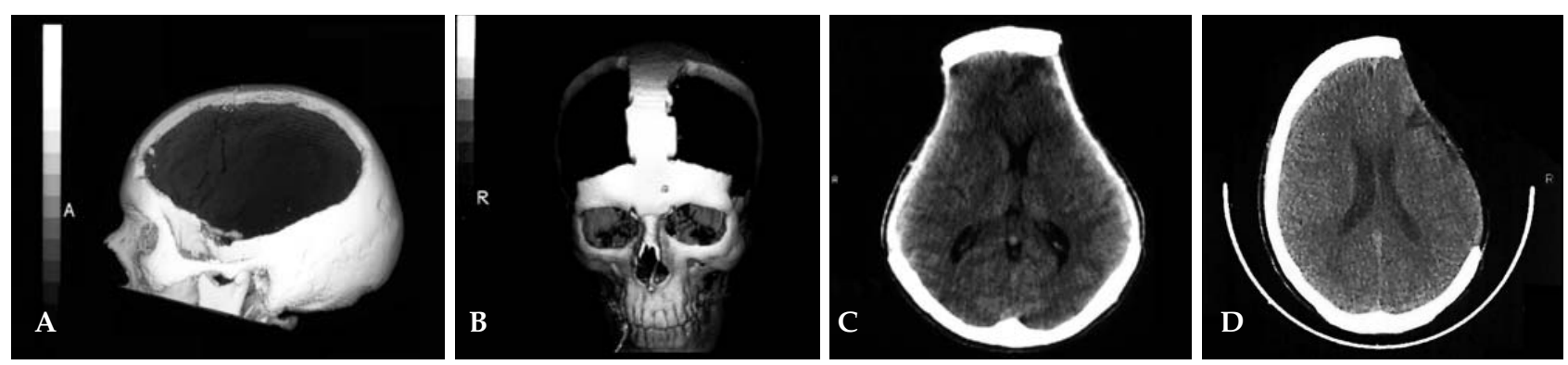

Figure 1: A) Representative neuroradiological studies obtained in patients with STBI. Craniectomy limits for unilateral DC; $3 D$ CT appearance. B) Representative neuroradiological studies obtained in patients with STBI. 3D CT showing craniectomy limits for bilateral DC. C) Representative neuroradiological studies obtained in patients with STBI. CT showing bilateral DC on postoperative 5 months. D) Representative neuroradiological studies obtained in patients with STBI. CT showing unilateral DC on postoperative 4 months. 
was performed using the Statistical Analysis System program for Windows (Release 9.0).

\section{RESULTS}

\section{Patient Population}

Group 1 comprised 36 (15 female, 21 male) STBI patients who underwent unilateral or bilateral DC. The mean age was $37.6 \pm 18.4$ years (range $17-68 \mathrm{yr}$ ), and the initial mean GCS score was $6.2 \pm 1.2$ points. Group 2 comprised 40 (16 female, 24 male) STBI patients who underwent rapid bilateral DC. The mean age was $41.3 \pm 17.2$ years (range 22-69 yr) and the initial mean GCS score was $6.4 \pm 1.3$ points. The differences between the groups in terms of age and initial GCS score were not statistically significant $(\mathrm{p}=0.786)$. Group 1 patients underwent surgical DC $35.7 \pm 5.6$ hours after trauma, while Group 2 patients underwent bilateral DC $4.3 \pm 1.5$ hours after trauma, which was a significantly shorter period of time. Details of patient age, gender, ISS, GCS, ICP, type of $\mathrm{DC}$, time of DC, and location of evacuated hematoma are shown in Table I. There was no difference between the groups in terms of mean ISS (Group $1=30 \pm 3$ points, Group $2=26 \pm 5$ ).

\section{Ventricular ICP Changes}

For both Groups 1 and 2, an EVD could not be inserted in only one patient (in group 1). For Group 1, the mean ICP values were $36 \pm 3.5(30-48) \mathrm{mm} \mathrm{Hg}$ before decompression and $23.3 \pm 3.5(16-34) \mathrm{mm} \mathrm{Hg}$ after decompression. This correlated well with the admission GCS. After DC, Group 1 patients showed a mean ICP decrease of $35.2 \%$. For Group 1, ICP decreases after DC were $21.5 \%$, for GOS 1 patients, $40.7 \%$ for GOS $2+3$, and $43,4 \%$ for GOS $4+5$ patients (Figure 2). For Group 2, the mean ICP values were $32.9 \pm 5.3(25-46) \mathrm{mm} \mathrm{Hg}$ during DC and $17.2 \pm 3.5$ (14 -27) $\mathrm{mm} \mathrm{Hg}$ after DC. This correlated well with the admission GCS. After DC, Group 2 patients showed a mean $47.7 \%$ decrease in ICP values was better than for Group 1. For Group 2, ICP decreases after bilateral DC were $33.6 \%$ for GOS 1 patients, $51.7 \%$ for GOS $2+3$, and $57.8 \%$ for GOS $4+5$ patients (Figure 2). There was a significant correlation between GOS score and ICP decrease for both groups.

\section{Outcome}

For Group 1, 27.8\% of patients had favorable outcomes and $72.2 \%$ had unfavorable outcomes 12 months after the trauma (Table II). For group 2, 50\%
Table I: Clinical and Neurological Data in Both Groups

\begin{tabular}{|c|c|c|}
\hline & $\begin{array}{l}\text { Group 1 } \\
(\mathrm{n}=36)\end{array}$ & $\begin{array}{c}\text { Group } 2 \\
(\mathrm{n}=40)\end{array}$ \\
\hline Age ,years, mean \pm sd & $37.6 \pm 18.4$ & $41.3 \pm 17.2$ \\
\hline Gender, male / female & $21 / 15$ & $24 / 16$ \\
\hline ISS, mean $\pm \mathrm{sd}$ & $30 \pm 3$ & $26 \pm 3$ \\
\hline GCS, mean \pm sd & $6.2 \pm 1,2$ & $6.4 \pm 1,3$ \\
\hline Average time of DC, & $35,7 \pm 5,6$ & $4,3 \pm 1,5$ \\
\hline hours Mean \pm sd & (25-47 h.) & $(2-8$ h. $)$ \\
\hline $\mathrm{ICP}, \mathrm{mmHg}$, mean $\pm \mathrm{sd}$ & $\begin{array}{c}36 \pm 3,5 \\
\text { (before DC) }\end{array}$ & $\begin{array}{c}32,9 \pm 5,3 \\
\text { (during DC) }\end{array}$ \\
\hline $\begin{array}{l}\mathrm{ICP}, \mathrm{mmHg} \text {, mean } \pm \mathrm{sd} \\
(\text { after DC) }\end{array}$ & $23,3 \pm 3,5$ & $17,2 \pm 3,5$ \\
\hline Unilateral DC & 22 & - \\
\hline Bilateral DC & 14 & 40 \\
\hline Swelling & 10 & 13 \\
\hline Contusion & 14 & 12 \\
\hline ASDH & 7 & 8 \\
\hline $\mathrm{ASDH}+$ Contusion & 4 & 5 \\
\hline $\mathrm{ASDH}+\mathrm{EDH}$ & 1 & 2 \\
\hline
\end{tabular}

ISS, Injury Severity Score; GCS, Glasgow Coma Score; ICP, intracranial pressure; ASDH, Acute subdural hematoma; EDH, Epidural hematoma; DC, Decompressive craniectomy; CT, Computerized tomography.

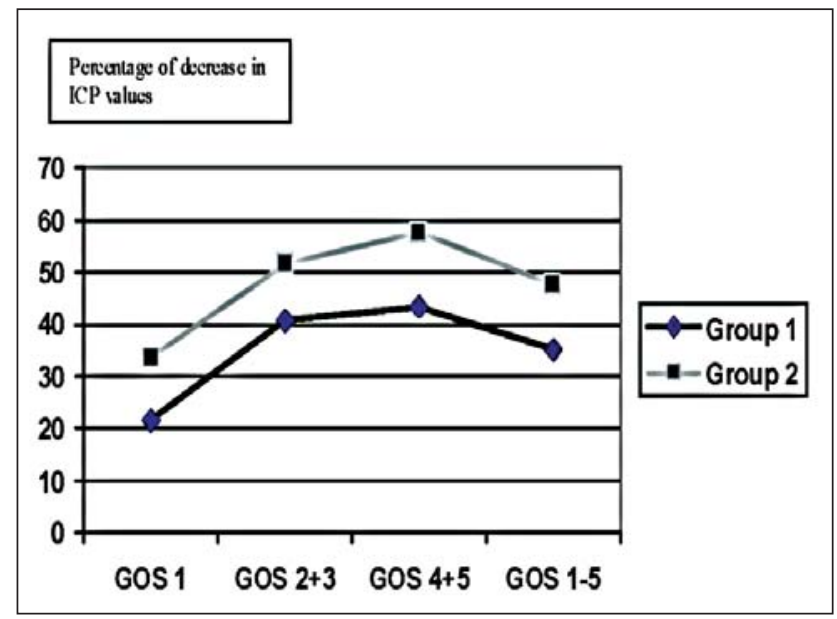

Figure 2: Graph showing summary of ICP decreases of patients for both groups after DC to GOS. 
of patients had favorable outcomes and $50 \%$ had unfavorable outcomes (Table II). This represented a statistically significant higher proportion of favorable outcomes in Group 2.The GCS score was strongly related to outcome (Table III). The outcome in patients with an initial GCS score of 6 or above was significantly better than that in patients with an initial GCS lower than 6 (Table III). The outcome in patients younger than 40 years was significantly better than that in older patients (Table IV).

\section{Operative and Postoperative Complications}

Cerebral edema was almost always present to result in bulging out of the craniectomy. Eleven patients developed some degree of subdural hygroma, of which seven required evacuation. Two patients developed epidural hematomas which necessitated evacuation. Two patients developed skim subdural hematomas that were not considered

Table II: Summary and Statistical Evaluation of Outcome of Both Groups

\begin{tabular}{|l|c|c|l|}
\hline & $\begin{array}{c}\text { Group1 } \\
(\mathbf{n}=\mathbf{3 6 )} \\
\mathbf{n}(\mathbf{\%})\end{array}$ & $\begin{array}{c}\text { Group } \\
\mathbf{2 ( n = 4 0 )} \\
\mathbf{n}(\mathbf{\%})\end{array}$ & P value \\
\hline GOS 4+5 & $10(27.8)$ & $20(50)$ & $\begin{array}{l}\mathrm{X} 2=3.92 \\
\mathrm{P}=0,047\end{array}$ \\
\hline GOS 2+3 & $10(27.8)$ & $15(37.5)$ & $\begin{array}{l}\mathrm{X} 2=0.81 \\
\mathrm{P}=0.36\end{array}$ \\
\hline GOS 1 & $16(44.4)$ & $5(12.5)$ & $\begin{array}{l}\mathrm{X} 2=9.67 \\
\mathrm{P}=0,0018\end{array}$ \\
\hline
\end{tabular}

GOS, Glasgow Outcome Scale

Table III: According to GCS Statistical Evaluation of Outcome of Both Groups

\begin{tabular}{|c|c|c|c|c|c|c|}
\hline & \multicolumn{2}{|c|}{ GOS 1} & \multicolumn{2}{|c|}{ GOS $2+3$} & \multicolumn{2}{|c|}{ GOS $4+5$} \\
\hline & $\begin{array}{c}\text { G1 } \\
n=16\end{array}$ & $\begin{array}{c}\mathrm{G} 2 \\
\mathrm{n}=5\end{array}$ & $\begin{array}{c}\mathrm{G1} \\
\mathrm{n}=\mathbf{1 0}\end{array}$ & $\begin{array}{c}\mathrm{G} 2 \\
\mathrm{n}=15\end{array}$ & $\begin{array}{c}\mathrm{G1} \\
\mathrm{n}=10\end{array}$ & $\begin{array}{c}\mathrm{G} 2 \\
\mathrm{n}=20\end{array}$ \\
\hline \multirow{2}{*}{$\begin{array}{l}\text { GCS4+5 } \\
\text { P value }\end{array}$} & 7 & 3 & 2 & 3 & 2 & 3 \\
\hline & \multicolumn{2}{|c|}{0.45} & \multicolumn{2}{|c|}{0.68} & \multicolumn{2}{|c|}{0.55} \\
\hline \multirow{2}{*}{$\begin{array}{l}\text { GCS } 6 \\
\text { P value }\end{array}$} & 5 & 1 & 3 & 3 & 4 & 5 \\
\hline & \multicolumn{2}{|c|}{0.62} & \multicolumn{2}{|c|}{0.45} & \multicolumn{2}{|c|}{0.33} \\
\hline \multirow{2}{*}{$\begin{array}{l}\text { GCS7+8 } \\
\text { P value }\end{array}$} & 4 & 1 & 5 & 9 & 4 & 12 \\
\hline & \multicolumn{2}{|c|}{0.66} & \multicolumn{2}{|c|}{0.46} & \multicolumn{2}{|c|}{0.25} \\
\hline
\end{tabular}

G1, Group 1; G2, Group 2; GCS, Glasgow Coma Scale; GOS, Glasgow Outcome Scale symptomatic nine patients with hydrocephalus had been placed a ventriculoperitoneal shunt. Five patients developed meningitis that was cured with antibiotics. Hypotension occurred in four patients for Group 1, in six patients for Group 2 (Table V). Other complications are listed in Table V.

\section{DISCUSSION}

Successful rehabilitation and achieving a favorable outcome following STBI is directly related to the degree of primary injury and effectiveness of early treatment. The common treatment for STBI is to stabilize the primary injury and eliminate conditions which may lead to secondary injuries. There are several treatments for uncontrollable ICP caused by STBI. In many neurosurgical centers, DC is perceived as a last resort for treating uncontrollable ICP to prevent disastrous outcomes $(20,22)$. The value of this surgical procedure as a second tier treatment

Table IV: Comparison of GOS according to Age

\begin{tabular}{|l|c|c|c|c|}
\hline & \multicolumn{2}{|c|}{$\begin{array}{c}\text { Group 1 } \\
\mathbf{n}=\mathbf{3 6}\end{array}$} & \multicolumn{2}{c|}{$\begin{array}{c}\text { Group 2 } \\
\mathbf{n = 4 0}\end{array}$} \\
\hline Age & $\begin{array}{c}\text { Age 40< } \\
\mathbf{n = 1 9}\end{array}$ & $\begin{array}{c}\text { Age 40> } \\
\mathbf{n = 1 7}\end{array}$ & $\begin{array}{c}\text { Age 40< } \\
\mathbf{n = 1 9}\end{array}$ & $\begin{array}{c}\text { Age 40> } \\
\mathbf{n = 2 1}\end{array}$ \\
\hline GOS 1+2+3 & 10 & 16 & 4 & 16 \\
\hline GOS 4+5 & 9 & 1 & 15 & 5 \\
\hline P value & \multicolumn{2}{|c|}{0,006} & \multicolumn{2}{c|}{0,001} \\
& \multicolumn{2}{|c|}{$\times 2=5.77$} & \multicolumn{2}{|c|}{$\times 2=10.03$} \\
\hline
\end{tabular}

GOS; Glasgow Outcome Scale

Table V: Complications Occurring in the Patients for the Two Groups

\begin{tabular}{|l|c|c|}
\hline & $\begin{array}{c}\text { Group 1 } \\
(\mathbf{n = 3 6 )} \\
\mathbf{n}(\%)\end{array}$ & $\begin{array}{c}\text { Group 2 } \\
(\mathbf{n = 4 0 )} \\
\mathbf{n}(\%)\end{array}$ \\
\hline Subdural Hygroma & $5(13.9)$ & $6(15)$ \\
\hline Epidural Hematoma & $1(2.8)$ & $1(2.5)$ \\
\hline Subdural Hematoma & $1(2.8)$ & $1(2.5)$ \\
\hline Posttraumatic Hydrocephalus & $4(11.1)$ & $5(12.5)$ \\
\hline Posttraumatic Rhinorrhea & $2(5.6)$ & $1(2.5)$ \\
\hline Hypotension & $4(11.1)$ & $6(15)$ \\
\hline Meningitis & $2(5.6)$ & $3(7.5)$ \\
\hline Septic Shock & $2(5.5)$ & $2(5)$ \\
\hline
\end{tabular}


remains controversial. Furthermore, studies so far are inconclusive regarding the indications for surgical decompression or optimal surgical technique.

The observations indicating that it is necessary to perform DC include dilated pupil, unresponsiveness to light, uncontrollable ICP values (greater than 30 $\mathrm{mm} \mathrm{Hg}$ ) for a period longer than 15 minutes and long-term failure to respond to maximal medical treatment methods $(10,25,26)$. Using these criteria, it is possible that the positive effects of DC are involuntarily restricted if indications for DC are planned as a second tier treatment. From this perspective, we explored the use of early bilateral DC as a first tier treatment in order to prevent secondary injuries that may occur during unsuccessful ICP treatment with conventional methods.

Following DC and dura opening, the edematous brain may herniate through the craniectomy opening rather than through the tentorial incisura, which prevents brainstem compression $(7,8)$. More sufficient decompression and suitable ICP decreases may be achieved if this extracalvarial movement is bilateral. Wolfa et al. reported the following formula for the brain tissue gradient in right frontal mass lesions: right frontal $=$ left frontal $>$ right temporal $=$ left temporal $>$ midbrain $>$ cerebellum $(28,29)$. Their formula for right temporal mass lesions was: right temporal $>$ left frontal $=$ left temporal $>$ right frontal $>$ midbrain $>$ cerebellum. Brain tissue pressure gradients indicate ICP increases for any lesion inside the head occur bilaterally. For this reason, we performed early DC as a bilateral frontotemporoparietal craniectomy as we believed this would be more effective in reducing ICP. The pressure gradients suggest that sufficient decompression may be achieved with a craniectomy involving frontal, parietal, and especially temporal regions. In our opinion, bilateral large craniectomy down to the base of the cranium prevents brainstem compression by the temporal lobe and therefore may improve patient outcome.

The age and GCS of the patient are major factors influencing DC effectiveness. It is generally reported that the outcome of patients younger than 50 years or with an initial GCS score of 6 or more is significantly better than that for older patients or those with an initial GCS score lower than 6
$(12,14,19,24,25,26)$. Consistent with those reports, our study found that patients younger than 40 years or with an initial GCS score 6 or more were more likely to have favorable outcomes. The factor of greatest influence on outcome is the time from injury to surgery. Patients that undergo DC within the first 4 hours following trauma have better outcomes compared to those who undergo DC after 4 hours $(2,13,25,26,30)$. Münch et al. reported a mortality rate of $30 \%$ for patients that underwent DC within 4 hours, compared to $90 \%$ for those after 4 hours (25). Polin et al. reported that patients who underwent bifrontal DC for post-traumatic cerebral edema within 48 hours had a $46 \%$ favorable outcome rate, while post- 48 hours patients had a $100 \%$ mortality rate (26). For this reason, some authors advocate that surgery should be undertaken within the first 48 hours of injury, before the period of maximal cerebral swelling $(23,26)$. Some clinicians suggest that neurons are not viable when cerebral blood flow and / or CPP is lower than critical values $(6,15,31)$. In the present study, Group 2 patients underwent bilateral early decompressive surgery as soon as possible after trauma. When compared to Group 1 outcomes, it appears this decision to operate as soon as possible led to a decreased mortality rate and an improved favorable outcome rate.

Decompressive craniectomy has been practiced since the early $19^{\text {th }}$ century by neurosurgeons. Different types of bone decompression have been attempted with variations in the location and size of bone removal depending on the cause of the elevated ICP $(1,3,4,5,11,16,17)$. In a study of 37 STBI patients aged under 40 years, Gaab prospectively performed bilateral DC on 19, and hemicraniectomy on 18 patients. He was unable to find any relationship between surgery type and clinical outcome (9). Polin et al., reported a favorable outcome rate of $37 \%$ in patients undergoing bifrontal decompression with dural expansion. They noted that decompressive bifrontal craniectomy has provided only a statistical advantage over medical treatment of intractable posttraumatic cerebral hypertension (26). DoSung Yoo reported a mortality rate of $20 \%$, an unfavorable outcome rate of $25 \%$ and a favorable outcome rate of $55 \%$ in STBI patients undergoing bilateral frontotemporaparieral DC (32). In the present study, Group 2 patients had a mortality rate of $12.5 \%$, an unfavorable outcome rate of $37.5 \%$ and a favorable outcome rate of $50 \%$. These patients underwent a 
large and bilateral DC, and the data suggest this choice of procedure may have as much influence on outcomes as time.

It is possible to evaluate the effect of DC on ICP. Do-Sung Yoo reported that when bilateral DC was performed on patients with bilateral diffuse cerebral edema, ICP values fell as much as 50\% compared to initial levels, and that dural expansion can further decrease ICP by as much as $35 \%$ (32). In a study of STBI patients, Polin et al. reported that bilateral DC resulted in a 33\% decrease in ICP compared to initial levels (26). In the present study, we found that early bilateral DC resulted in a $48 \%$ decrease in ICP.

The present data indicate that rapid and large bilateral DC is more effective than any other type of decompressive surgery for treating elevated ICP in STBI patients. Improved ICP resulted in a reduced mortality rate and an improved favorable outcome rate, especially in GCS 6-8 patients.

This study was not a randomized or blinded study because of the observational nature of the study design. The two groups of patients were studied at different time periods. The same medical therapy was performed for both groups. The actual procedure was different in the two groups. Generally accepted concept like many the preceding reports was performed for group 1, however early bilateral DC was hypothesis. Moreover blinding of outcome assessment is difficult in surgical studies. It may be a profound limitation regarding validity of results. Thus, it may limit the strength of result of outcome. The limitations was inherent.

\section{CONCLUSION}

To obtain favorable outcomes in STBI patients, early decision making and proper patient selection are important. Further clinical studies on early bilateral DC are required to confirm its beneficial effects on clinical outcomes, and to provide further evidence as to whether this procedure should be used as a first tier treatment.

\section{ACKNOWLEDGMENTS}

We thank the nurses of the Department of Neurosurgery and Intensive Care Unit for skillful help and cooperation in performing this study.

This study was supported by the Akdeniz University Research Foundation.

\section{REFERENCES}

1. Alexander E, Ball MR, Laster DW: Subtemporal decompression: Radiological observations and current surgical experience. J Neurosurgery 1:427-433, 1987

2. Becker DP, Miller JD, Ward JD, Greenberg RP, Young HF, Sakalas R: The outcome from severe head injury with early diagnosis and intensive management. J Neurosurg 47: 491502,1977

3. Carter BS, Ogilvy CS, Candia GJ, et al.: One-year outcome after decompressive surgery for massive nondominant hemispheric infarction. Neurosurgery 40: 1168-1176,1997

4. Clark K, Nash TM, Hutchison GC: The failure of circumferential craniotomy in acute traumatic cerebral swelling. J Neurosurg 29:367-371, 1968

5. Cooper PR, Haggler H, Clark WK, et al.: Enhancement of experimental cerebral edema after decompressive craniectomy: Implications for the management of severe head injuries. Neurosurgery 4: 296-300, 1979

6. Dickman CA, Carter LP, Baldwin HZ, et al.: Continuous regional cerebral blood flow monitoring in acute craniocerebral trauma. Neurosurgery 28: 467-472, 1991

7. Doerfler A, Forsting M, Reith W, Staff C, et al.: Decompressive craniectomy in a rat model of "malignant" cerebral hemispheric stroke: Experimental support for an aggressive therapeutic approach. J Neurosurg 85: 853-859, 1996

8. Engelhorn T, Doerfler A, Kastrup A, Beaulieu C, et al.: Decompressive craniectomy, reperfusion or a combination for early treatment of acute "malignant" cerebral hemispheric stroke in rats? Potential mechanism studied by MRI. Stroke 30 (7): 1456-1463, 1999

9. Gaab MR, Rittierodt M, Lorenz M, Heissler HE: Traumatic brain swelling and operative decompression: A prospective investigation. Acta Neurochir Supp (Wien). 51: 326-328, 1990

10. Gerl A, Tavan S: Bilateral craniectomy in the treatment of severe traumatic brain edema. Zentrabl Neurochir. 41: 125138,1980

11. Gower DJ, Lee KS, Mc Whorter JM: Role of subtemporal decompression in severe closed head injury. Neurosurgery 23: 417-422, 1988

12. Guerra WK, Gaab MR, Dietz H, et al.: Surgical decompression for traumatic brain swelling; indications and results. J Neurosurg 90 (2):187-196, 1999

13. Haselsberger K, Pucher R, Auer LM: Prognosis after acute subdural or epidural hemorrhage. Acta Neurochir (Wien) 90:111-116, 1988

14. Ivamoto HS, Numoto $M$, Donaghy RMP: Surgical decompression for cerebral and cerebellar infarcts. Stroke 5: 365-370, 1974

15. Kalia KK, Yonas H: An aggressive approach to massive middle cerebral infarction. Arch Neurol. 1993; 50: 1293-1297

16. Kjellberg RN, Prieto A JR: Bifrontal decompressive craniotomy for massive cerebral edema. J Neurosurg 34: 488493, 1971

17. Kondziolka D, Fazl M: Functional recovery after decompressive craniectomy for cerebral infarction. Neurosurgery 23: 143-147, 1988

18. Kunze E, Meixenberger J, Janka M, Sorensen S, Roosen K: Decompressive craniectomy in patients with uncontrollable intracranial hypertension. Acta Neurochir Suppl (Wien) 71: 16-18, 1998 
19. Maas AIR, Dearden M, Teasdale GM, Braakman R, et al.: EBIC guidelines for the management of severe head injury in adults. Acta Neurochir (Wien) 139: 286-294, 1997

20. Marshall LF: Head injury. Recent past, present, and future. Neurosurgery 47 (3): 546-561, 2000

21. Marshall LF, Gautille T, Klauber MR: The outcome of severe closed head injury. J Neurosurg 75: 28-36, 1991

22. Marshall LF, Marshall SB, Klauber MR et al.: A new classification of head injury based on computerized tomography. J Neurosurg 75:14-20, 1991

23. Mc Kinley BA, Parmley L, Tonneson AS: Standardized management of intracranial pressure: a preliminary clinical trial. J Trauma 46 (2):271-280, 1999

24. Morgalla MH, Krasznail L, Buchholz R, et al.: Repeated decompressive craniectomy after head injury in children: Two successful cases as result of improved neuromonitoring. Surg Neurol. 43 (6): 583-589, 1995

25. Münch E, Horn P, Schürer L, Piepgras A, et al.: Management of severe traumatic brain injury by decompressive craniectomy. Neurosurgery 47 (2):315-323, 2000

26. Polin RS, Shaffrey ME, Bogaev CA, et al.: Decompressive bifrontal craniectomy in the treatment of severe refractory posttraumatic cerebral edema. Neurosurgery 41 (1):84-92, 1997
27. Teasdale GM, Drake CG, Hunt W, Kassell N, Sano K, Pertuiset B, De Villers JC: A universal subarachnoid hemorrhage scale. Report of a committee of World Federation of Neurosurgical Societes. J Neurol Neurosurg Psychiatry 51:1457-1458, 1988

28. Wolfla CE, Luerssen TG, Bowman RM, et al.: Brain tissue pressure gradients created by expanding frontal epidural mass lesion. J Neurosurg 84: 642-647, 1996

29. Wolfla CE, Luerssen TG, Bowman RM: Regional brain tissue pressure gradients created by expanding extradural temporal mass lesion. J Neurosurg 86: 505-510, 1997

30. Yamakami I, Yamura A: Effects of decompressive craniectomy on regional cerebral blood flow in severe head trauma patients. Neurol Med Chir (Tokyo). 33 (9): 616-620, 1993

31. Yonas H, Gur D, Claassen D, et al.:Stable xenon -enhanced CT measurement of cerebral blood flow in reversible focal ischemia in baboons. J Neurosurg 73: 266-273, 1990

32. Yoo Do-Sung, Kim Dal-Soo, Cho KS, et al.: Ventricular pressure monitoring during bilateral decompression with dural expansion. J Neurosurg 91:953-959,1999 